\title{
272. Die Leistungsfähigkeit autologer Spongiosa für die Behandlung knöcherner Defekte
}

\author{
E. H. KUNER* und F. WEYAND-Freiburg
}

The Effectiveness of Autologous Spongy Tissue Grafts in the Treatment of Bone Defects

Summary. Fractures in the region of the shaft and joint of the long bones, pseudo-arthroses, chronic osteomyelitis and certain bone tumours are indications for the transplantation of autologous spongy bone tissue. The effectiveness of autologous spongy bone grafts, due to the rapid healing and structural transformation obtained, makes them one of the best materials available for repairing bone defects. It is immaterial whether the bone defect is due to mechanical or inflammatory factors or whether it is the result of a tumour.

It is essential, however, that any break in the bone is temporarily immobilised by osteosynthesis and that the host tissue is capable of regeneration.

The satisfactory healing into position and functional performance of autologous grafts of spongy bone tissue is demonstrated in a case of an extensive defect at the distal end of the tibia caused by a fracture, in another case of a multiple fracture of the femur, in two cases of osteomyelitis of the tibia with extensive loss of tissue and in a case of a giant-cell tumour of the neck of the femur.

Zusammenfassung. Frakturen im Schaft- und Gelenkbereich großer Röhrenknochen, die Pseudarthrosen, die chronische Osteomyelitis und bestimmte Knochentumoren gelten als Indikation für die autologe Spongiosaplastik.

In der Leistungsfähigkeit liegt die autologe Spongiosa auf Grund ihrer raschen Einheilung und ihres Strukturumbaues in der Behandlung knöcherner Defekte an erster Stelle. Dabei ist es gleichgültig ob dieser mechanisch, entzündlich oder durch Tumorwachstum entstanden ist.

Voraussetzung ist allerdings, daß die Kontinuitätstrennung temporär durch stabile Osteosyntheseverfahren neutralisiert wird und das Lagergewebe ersatzkräftig ist.

Anhand einer ausgedehnten Defektfraktur am distalen Tibiaende, an einem Mehrfragmentenbruch des Femur, an 2 Fällen einer Osteomyelitis der Tibia mit großem Substanzverlust und an einer Riesenzellgeschwulst des Schenkelhalses wird der funktionsgerechte Einbau der autologen Spongiosa demonstriert.

\section{Der biologische Wert des corticospongiösen Eigenspanes gegenüber dem Fremdspan beim Knochenersatz am Handskelet}

\section{H. WILLEBRaND* und K.-D. HöHLE-Mainz}

The Biological Value of Cortico-Spongiosa Auto-Chips Compared with Heterologous Chips when Replacing Bone in the Skeleton of the Hand

Summary. The cortico-spongiosa auto-chip is superior to the heterologous chip (Kieler chip) in view of its later functional effectiveness in transplantations into 